\title{
Diagnosis of the balneability conditions of Beira Rio beach in the municipality of Porto Nacional, Tocantins
}

The Tocantins River has great water resources and it has been highly sought after for recreational activity, and it is highlighted for the beautiful beaches that are formed in its extension. It is important to remember that primary contact recreation and leisure activities have a specific criterion of sanitary safety for the purpose of balneability. This study evaluated the water quality of Beira Rio Beach in Porto Nacional - Tocantins. Microbiological analyses were performed using the indicators of the total coliform group and Escherichia coli (E. coli). The results of the monitoring were checked with the parameters established for balneability purposes defined by CONAMA Resolution No. 274/00. The Colilert technique was used for detections and confirmatory identifications of total coliforms and E. coli. Low concentrations of E. coli were proven, which allowed the final classification in the category of 'excellent', according to CONAMA Resolution No. 274/00. Therefore, the waters of Beira Rio Beach, in the period of analysis and collection of samples, based on the indicator of bacteria of the E. coli group, were found within the accepted standards for balneability (primary contact recreation).

Keywords: Balneability; Water Quality; Beira Rio Beach

\section{Diagnóstico das condições de balneabilidade da praia do Beira Rio no município de Porto Nacional, Tocantins}

O Rio Tocantins possui grandes recursos hídricos e tem sido muito procurado para a atividade recreativa, sendo destaque pelas belas praias que se formam em sua extensão. É importante lembrar que as atividades de recreação e lazer de contato primário possuem um critério específico de segurança sanitária para fins de balneabilidade. Este estudo avaliou a qualidade da água da Praia Beira Rio em Porto Nacional - Tocantins. As análises microbiológicas foram realizadas utilizandose os indicadores do grupo coliforme total e Escherichia coli (E. coli). Os resultados do monitoramento foram verificados com os parâmetros estabelecidos para fins de balneabilidade definidos pela Resolução CONAMA no 274/00. A técnica de Colilert foi usada para detecções e identificações confirmatórias de coliformes totais e E. coli. Foram comprovadas baixas concentrações de E. coli, o que permitiu a classificação final na categoria 'excelente', de acordo com a Resolução CONAMA no 274/00. Portanto, as águas da Praia do Beira Rio, no período de análise e coleta de amostras, com base no indicador de bactérias do grupo E. coli, se encontraram dentro dos padrões aceitos para balneabilidade (recreação de contato primário).

Palavras-chave: Balneability; Qualidade da água; Praia da Beira Rio.

Topic: Engenharia de Recursos Hídricos

Reviewed anonymously in the process of blind peer.
Received: 08/07/2020

Approved: 21/10/2020

Paulo Victor Ferreira de Souza

Instituto Tocantinense Presidente Antônio Carlos, Brasil

paulovictoritpac@gmail.com

Ângelo Ricardo Balduino (iD

Instituto Tocantinense Presidente Antônio Carlos, Brasil

http://lattes.cnpq.br/8475669590774317

http://orcid.org/0000-0002-7082-2566

angelo@ifto.edu.br

Referencing this:

SOUZA, P. V. F.; BALDUINO, Â. R.. Diagnosis of the balneability conditions of Beira Rio beach in the municipality of Porto Nacional, Tocantins. Natural Resources, v.10, n.3, p.68-76, 2020. DOI: http://doi.org/10.6008/CBPC2237-9290.2020.003.0008 


\section{INTRODUCTION}

Water is a fundamental element for the sustaining of life, and this resource takes on several uses, depending on each demand, it's essential for human consumption, animal, primary contact recreation, commercial, industrial, agricultural, transport, sewage disposal and garbage. Since it is a restricted resource that depends on the natural processes to resurface, whose cycle requires longer time for the resurgence, the ability of the user to pollute water is much faster, there is an imbalance between the process of the cycle of water resurgence and the misuse of it, this happens because there are a number of environmental problems, such as contamination of water resources and the risk of water scarcity on the planet.

The devices that pollute the water, travel several paths until reaching the aquatic environment, being able to be either in the soil, in the atmosphere or can be dumped directly in the river. They are sources that occur due to the release of domestic and industrial sewage without necessary treatment, pesticide products in agriculture. These are the factors that cause excess imbalances to the aquatic environment and, consequently, generate great risks to the health of users.

In this sense, it is necessary to highlight that Brazil is considered privileged in terms of its natural resources, it has a vast and rich biodiversity. The fresh water in the country is in large quantities and a considerable part of the coasts are bathed by warm waters, which means, Brazil is surrounded by beautiful scenery, which ends up being inviting the balneability and attracts tourists from all over the world.

The multiple uses of water in the hydrographic region of Tocantins include irrigation, power generation, recreation, fishing, and tourism. It moves the economy of the region and it generates employment and income for many families. The macrophiles are originated due to the rotting of the leaves and stems of the riparian forest and the proliferation of aquatic plants, all of this causes major environmental problems because the aquatic environment is modified, and eutrophication occurs which are the presence of organic matter in water. For recreational purposes, these factors make it impossible to use this water.

The neglects with septic tank can greatly hinder the lives of the people of Porto Nacional, when submerged, they represent major risk factors of contamination of the water of Beira Rio Beach due to the concentration of microbiological indicators fecal coliforms (thermotolerant) and Escherichia coli and these contaminations prevent the use of water, because it loses a lot of its quality for the recreational use of direct and prolonged contact.

Water is a natural element extreme essential for humans to survive. With each passing day it has become increasingly a scarce resource that needs full attention, it has several uses and it is for everyone. The dependence of fresh water has always been great in the present and in the past for survival, great conflicts are generated due to society entering into a certain dispute to ensure the power of water, for economic and cultural development purposes (ALAMINO et al., 2005).

According to Embrapa (2020), the Brazilian agriculture is seen as a human activity that consumes more drinking water, in the future agriculture will need a solution to depend less and less on water in a coherent way. One of the projects will be to implement solutions for plants that do not depend so much on 
irrigation to further reduce their dependence on water resources.

According to Silva et al. (2014), the use of irrigation in agriculture is very wide, for this reason, future generations need to find a way to produce better and on a large scale to save water resources. Therefore Embrapa (2020), says that after the use of water in its cycle a great consistency of impurities remains on it, and this contamination can also damage the underground water and contaminate the rivers.

The United Nations World Report on the Development of Water Resources (World Water Assessment Programme), led by UNESCO, says that water demand has great influence due to agriculture, industries, urban development, energy sector and domestic users. Finally, a competition is generated between the uses of water, increasing the risk of conflicts and disparities in access to services are installed, with negative economic impacts and damage to the health of human well-being.

The National Environment Council - CONAMA (2000) defines that the recreation of primary contact is linked with the direct contact of the user with the water course, through the performance of diving, swimming and water skiing practices, in which the possibility of swallowing a certain amount of water is manifested.

Water has always been linked with the history of human civilization, because it is very important to develop several activities essential to human survival: domestic and industrial storage, as well as energy production, sewage displacement, fishing, recreation and leisure. Formerly the use of water in relation to Balneability mark 300 years BC, corresponding to the time of the Egyptian empire (SPERLING et al., 2010).

Barros et al. (2015), say that Resolution No. 274 of November 29, 2000, of the National Environment Council - CONAMA, is the legislation that regulates the assessment of the sanitary quality of water for balneability, in which the number of indicator organisms present in human waste, or warm-blooded animals, are measured. After the tests are done, the water is classified as proper or improper.

According to BRK Ambiental, the dumping of sanitary sewage in inappropriate places such as in bathing places within the urban space, generate environmental impacts for the entire ecosystem of that river or lake compromising the quality of the water for recreation purposes, harming not only the bath, but also the fish that are fished in that place.

The large exposure to violet rays can cause damage to the skin, to the immune system and to the vision. Erythema is the most acute effect of excessive exposure to violet rays; it is an inflammation of the skin that is known as sunburn. The exposure to rays also generates other effects, which are photokeratitis and photo conjunctivitis. The chronic effects are skin cancer and cataract, but there is still the possibility of exposure to cause degenerative changes in the skin, such as freckles and the acceleration of aging (BARROS et al., 2015).

According to Lopes et al. (2010), the use of water resources for recreational purposes has expanded and acquired social and economic importance over the past years. Primary contact recreation is highlighted among these activities, waterfalls, river beaches and reservoirs. These natural resorts generate great interests for people, they intensify tourism and ecotourism, and finally, transform them into economic sources of sustainable development. 
Resolution 274/00 of the NATIONAL ENVIROMENT COUNCIL - CONAMA (2000) has defined that fresh, brackish and saline waters will have the quality levels evaluated by specific parameters and indicators, in order to ensure the conditions of Balneability (primary contact recreation such as diving, swimming, water skiing and sport fishing). Following this aspect, the Most Probable Number (MPN/100ml of water) of the fecal coliforms group (thermotolerant) and Escherichia coli present in the waters of Beira Rio beach, Tocantins River basin, will be determined.

Therefore, this project was developed with the intention of evaluating the water quality conditions for bathing purposes (primary contact recreation), through the microbiological analysis of the group of total coliforms and Escherichia coli at a point on the Beira Rio beach in Porto National, and also make the result of this monitoring analysis available to the sector responsible for tourism, the government and also the whole community.

\section{MATERIALS AND METHODS}

\section{Monitoring Point}

The research project is an experimental research with a descriptive analysis that was carried out surveys in loco, aiming to obtain an evaluation of the conditions of Beira Rio beach, and the study was defined through the point of collection and analysis of water.

The chosen area that was carried out this work was the beach formed next to Beira Rio Avenue and it belongs to the basin of the Tocantins River that passes through the municipality of Porto Nacional it is situated in the geographic center of the State, in the eastern mesoregion, it has an average altitude of 210 meters above sea level, a surface of $4,449.8 \mathrm{~km}^{2}$ and has as coordinates $S 10^{\circ} 41^{\prime} 51^{\prime \prime}$ latitude and W $48^{\circ} 24^{\prime} 52^{\prime \prime}$ west longitude.

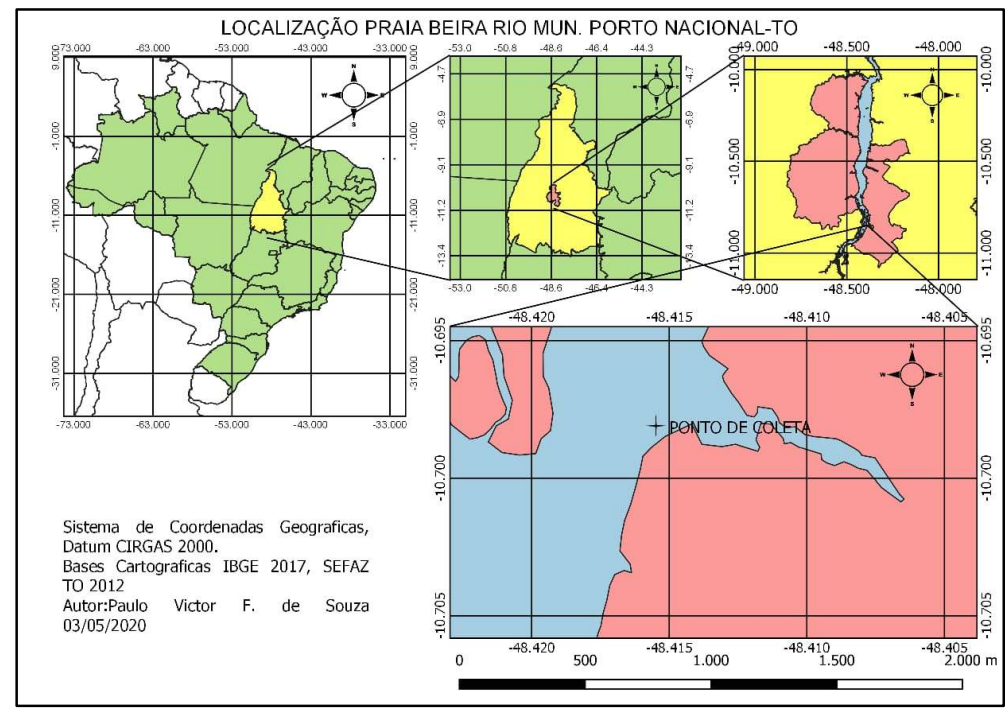

FIgure 1: Location of sampling points at Beira Rio Beach in Porto Nacional/TO.

Translation of the words of the figure

Localização da Praia Beira Rio Mun Porto Nacional/TO -

Beira Rio Beach Location Mun Porto Nacional Beach TO

Sistema de coordenadas geográficas DETUM Cirgas 2000 Bases Cartográficas IBGE 2017
SEFAZ TO 2012 Autor Paulo Victor F. de Souza 03/05/2020 - Geographic coordinate system DATUM Sirgas 2000 Cartographic Bases IBGE 2017 SEFAZ TO 2012 Author Paulo Victor F. de Souza 05/03/2020 


\section{Studies Conducted}

For the study in the Tocantins river basin on Beira Rio beach, the tests of Total Coliforms and Escherichia Coli, pH analysis, turbidity and electrical conductivity were performed according to the Standard Methods (APHA, 2005). The fecal coliform assay aims to verify the presence and number of fecal bacteria in the water sample collected from the beach. This bacterium can transmit diseases such as hepatitis or it can be the causative agent of gastrointestinal problems (INMETRO, 2018).

In this project, during the months of February and March, in six weeks, 6 water samples (microbiological and physical-chemical) were monitored, the samples were collected and transported to the laboratory on the same day for analysis. For the parameters of $\mathrm{pH}$, electrical conductivity and turbidity, they were made in loco, and the conductivity meter was used for the parameter of electrical conductivity, the turbidimeter was used for turbidity parameter and the $\mathrm{pH}$ meter equipment was used for the $\mathrm{pH}$ parameter according to the protocols of use of these equipment.

The samples were collected once a week, at the chosen collection point, sterile glass containers of $100 \mathrm{ml}$ were used, approximately $25 \mathrm{~cm}$ deep. The chosen point for collection was selected according to criteria established by Conama $\mathrm{N}^{\circ} .274 / 2000$, following Art. 5th, which says that the point will be where to find the largest concentration of people bathing on the beach.

The microbiological and physical-chemical samples were collected in $100 \mathrm{ml}$ bottles, then they were placed in thermal boxes containing ice and taken to be processed in the laboratory of IFTO - Federal Institute of Education, Science and Technology of Tocantins, in Porto Nacional. In art. 20 (CONAMA, 2000), the fresh, brackish, and saline waters destined to balneability (primary contact recreation) had their condition evaluated in proper and improper categories, as shown in table 1.

Table 1: Limit of fecal coliforms, Limit of Escherichia coli and percentage of time according to its categories.

\begin{tabular}{ll|ll}
\hline \hline Category & $\begin{array}{l}\text { Limit of fecal coliforms (thermotolerant) } \\
\text { (Most Probable number per 100ml) }\end{array}$ & $\begin{array}{l}\text { Escherichia coli limit (Most } \\
\text { Probable Number per 100ml) }\end{array}$ & Percentage of time \\
\hline Proper Water & & & \\
\hline Excellent & 250 & 200 & Maximum values at $80 \%$ or \\
Very Good & 500 & 400 & more of the time \\
Satisfactory & 1.000 & 800 & Higher than the value \\
\hline & Improper water category & & indicated in 20\% of the time \\
\hline
\end{tabular}

For the fecal coliform assay, CONAMA Resolution (2000) determines that at least $80 \%$ of the samples analyzed have a bacteria count of less than 1000 per $100 \mathrm{ml}$ of sample, so that the balneability of the beach is considered satisfactory (INMETRO, 2018).

Conama Resolution No. 274 (2000) also says that if the environmental control body finds that there is poor quality of recreational waters the stretches of beaches and resorts will be banned if the environmental control body, in any of its instances (municipal, state or federal), finds that the poor quality of the primary contact recreation waters justifies the measure. 


\section{Sample Collection Procedure}

The samples were collected once a week, at the chosen collection point, sterile glass containers of $100 \mathrm{ml}$ were used, approximately $25 \mathrm{~cm}$ deep. The chosen point for collection was selected according to criteria established by Conama $\mathrm{N}^{0} \cdot 274 / 2000$, following Art. $5^{\text {th }}$, which says that the point will be where to find the largest concentration of people bathing on the beach.

In the collection of the material for data analysis, disposable gloves, sterilized bottles and new bags were used to place the bottles after they were collected, and the samples collected in the field were stored in a thermal box with ice and then transported to the IFTO chemistry laboratory.

\section{Laboratory Analysis Method}

The collected samples were transported to the IFTO laboratory - Campus Porto Nacional, from there microbiological analyses on the $E$. coli group were initiated, based on the collilert technique according to the methodology described by Standard Methods (APHA, 2005).

The Colilert method is widely used in this type of research. The culture medium (Colilert enzyme) is already in the right amount for the analysis of $100 \mathrm{ml}$ of water; each enzyme will be added to the $100 \mathrm{ml}$ bottle with the sample that was collected and stirred until the granules are completely diluted. After that, the solution was incubated at 35으 in a laboratory oven for 24 hours. CONAMA Resolution 274/2000 will determine the parameters to be followed. The microbiological indicator parameter of balneability are fecal coliforms according to CONAMA resolution 274/2000.

\section{RESULTS AND DISCUSSION}

The monitoring of water quality of this study occurred during the months of February and March 2020, period of rain and drought. During the rainy season, the water presented a dark coloration due to the movement of solids to the riverbed. In the dry season, the water presented a transparent coloration. However, the color of the water does not characterize evidence of contamination, because even exhibiting a transparent color it can be contaminated.

At the end of the analyses, all water samples showed a yellow color and fluorescence characteristics, evidencing the presence of bacteria from the group of total coliforms and $E$. coli. The results obtained remained above the values recommended by CONAMA resolution 274 of 2000, which defines that when in $80 \%$ or more of a set of samples obtained in each of the five weeks, is found at most, 200 Escherichia coli, the waters are considered proper and falls into the category of 'excellent' for balneability purposes. The graph 1 shows the results of e. coli bacterial analyses. E. coli. present at the monitored point. 


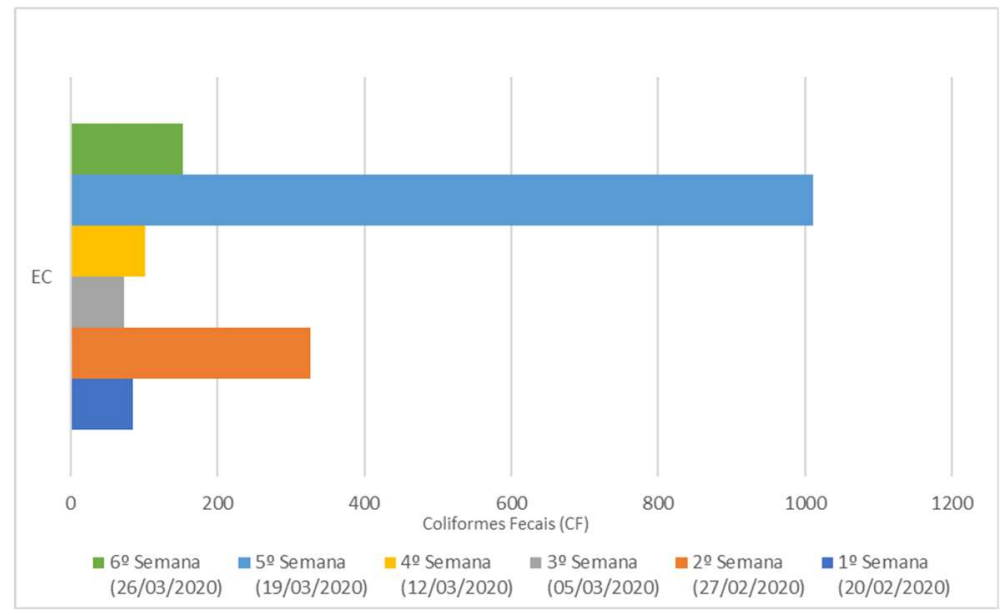

Source: Own Elaboration (2020)

Translation of the words of the figure

$1^{\text {o. }}$ Semana $(20 / 02 / 2020)-1^{\text {st }}$ week $(02 / 20 / 2020)$

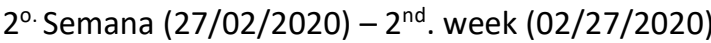

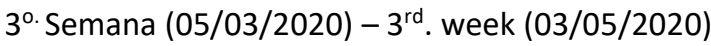

$4^{\text {o. Semana }}(12 / 03 / 2020)-4^{\text {th }}$. Week $(03 / 12 / 2020)$

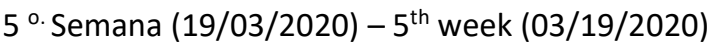

$6^{\text {o. }}$ Semana $(26 / 03 / 2020)-6^{\text {th }}$ week $(03 / 26 / 2020)$

Coliforme Fecais (CF) - Fecal Coliform (FC)

The results follow the weightings based on the characteristics of the sample collection point. The chosen point represents the shallow part of the Beira Rio beach, approximately $20 \mathrm{~m}$ from the river bank, specifically behind the Choperia Beira Rio, this point being used for primary contact recreation. Considering what was calculated, only one sample passed the standard, finally the analysis was satisfactory, because $83.33 \%$ of the samples had a bacteria count lower than 1000 per $10 \mathrm{ml}$ of sample.

When analyzing the water samples from the chosen point, it was found that the density of $E$. coli varied from 72.0 to 1011.2 (MPN/100ml) during the monitoring period. The lowest levels of bacteria are seen in the first $(2 / 20)$ and third $(3 / 5)$ week, while the highest concentrations are present in the fifth (3/19) and second $(2 / 27)$ week. The greater presence of E. coli was observed in the period when there was high rainfall in the previous day. The rain may have interfered with the result, considerably increasing the contamination rate by approximately $587 \%$ compared to the average of the other five weeks in which there was a drought.

Many bacteria are identified in the rainy season, this high concentration can be explained by the fact that when rainwater drains through the soil, it carries numerous impurities to the riverbed that originate from solid residues from the toxic substance found on the surface of the earth and feces of animals, compromising the quality of bathing water.

The navigation of boats that navigate there may also play a major role in increasing the index, since the emission of combustible oil residues that leave the engines of vessels used to transport people, are a source of water contamination. The uncontrolled growth of tourism and recreation activities generate major problems, such as waste from vessels that sail and expel gases, oils and greases, due to the lack of garbage collection and also due to the lack of guidance from users.

The results of microbiological analyses of the chosen point, even with high counts of $E$. colli bacteria, based on conama resolution $274 / 00$ criteria, showed that water meets the criteria of proper for use in primary contact recreation. When analyzing the water samples from the chosen point, it was verified that the density of $E$. coli presented a variation from 72.0 to 1011.2 (MPN/100ml) during the monitoring period. 
Souza et al. (2016) in a study at Beira Rio Beach also in Porto Nacional, did a quality work and obtained lower values ranging from 14.4 to 56.9 (MPN/100 ml), having an analysis period from February to June 2016, this means that over the course of a year, water underwent a major change in its composition, that is, a large number of Escherichia Coli a was present at that place.

Silva et al. (2019) also presented the average of a number below that of the article presented, having the period of analysis that went from April to July, and he obtained results between 12.6 to 325.7 (MPN/100ml), this shows that each year passing the water quality for recreation purposes is getting even worse .Although these numbers are high, according to CONAMA Resolution 274 of 2000, water meets criteria as proper for balneability purposes.

\section{CONCLUSIONS}

The results obtained through microbiological analyses of water samples collected at Beira Rio Beach in Porto Nacional/TO, confirmed that E. Colli bacteria were present throughout the study period at the monitoring point. This research was carried out in order to evaluate the quality conditions of the beach water for the purpose of primary contact recreation, through indicators of fecal pollution, such as bacteria from the total coliform group and E. coli. Comparing the results obtained from the analyses with the values suggested by CONAMA resolution $274 / 00$ for primary contact recreation, it was classified as 'excellent', that is, water proper for use.

The evaluation of the parameters of balneability of the waters of Beira Rio Beach, in the monitoring period, confirms that the place presented proper conditions for use in primary contact recreation. Therefore, due to hit has presented a certain concentration of $E$. colibacteria, it is necessary to make some recommendations to maintain control of preventive practices of water quality for balneability purposes: a) Define a water monitoring program as an appropriate practice to provide greater health security to bathers and stimulate the use of the beach throughout the year as a pleasant environment for recreation and leisure; b) Application of legislation instruments to contain the spread of contamination, such as the criteria determined by CONAMA Resolution N N. $^{\circ} 74 / 00$ and Environmental Legislation; c) Perform constantly the cleaning of the riverbanks and waste to prevent them from being taken to the water body during the rainy season; d) Encourage the Population of Porto Nacional to inform themselves about water quality conditions before using it for recreation purposes; e) Install boards around the place to keep bathers informed about the safety and quality of water use for recreation.

In order to keep the environment free of contamination and clean, the final results of the analyses will be passed on to the State and Municipal Secretariat of the Environment, with a focus on developing preventive actions through scientific research, through partnerships with educational institutions. All this will offer greater security to the population of Porto Nacional and the tourists, and it will also develop tourism and the economy of the municipality of Porto Nacional/TO. 


\section{REFERENCES}

ALAMINO, A. L. M.; PEREIRA, D. L. T.; LIMA, E. Y. A.; ALAMINO, N. M.; FACCIO, N. B.; ROCHA, R. R. A.. Qualidade da água: conservação, preservação e educação ambiental: conscientizando alunos de 5 a série. Monografia (Especialização) - Escola Estadual Maria Luiza Formozinho Ribeiro, Presidente Prudente, 2005.

APHA. American Public Health Association. Standard methods for the examination of water and wastewater. 21 ed. Washington: APHA, 2005.

BARROS, D. J.; MARQUES, A. K.; MORAIS, P. B.. Avaliação ambiental com base em indicador microbiológico de balneabilidade no município de Palmas/TO. J. Bioen. Food Sci., v.2, n.4, p.172-177, 2015. DOI: http://doi.org/10.18067/jbfs.v2i4.65

EMBRAPA. Água na agricultura com planejamento e gestão não há crise hídrica. EMBRAPA, 2020.

INMETRO. Portal de Serviços do Inmetro. Informação ao consumidor. INMETRO, 2018.
LOPES, F. W. A.; MAGALHÃES JUNIOR, A. P. M.. Avaliação da qualidade das águas para recreação de contato primário na bacia do Alto Rio das Velhas/MG. Revista Brasileira de Geografia Médica e da Saúde, v.6, n.11, 2010.

SILVA, A. P.; LIMA, D. P.; BALDUINO, A. R.. Diagnóstico das condições de balneabilidade da Praia Beira Rio do município de Porto Nacional (TO). Engineering Sciences, v.7, n.2, p.5359, 2019.

SILVA, W. R.; SILVA, M. R.; PIRES, T. B.. O uso sustentável e a qualidade da água na produção animal. Revista Eletrônica Nutrime, v.11, n.5, p.3617-3636, 2014.

SOUZA, I. N. C.; BALDUINO, A. R.; GOMES, S. B.. Avaliação das condições de balneabilidade da praia Porto Real em Porto Nacional/Tocantins. Araguaína: Instituto Tocantinense Presidente Antônio Carlos, 2016.

SPERLING, E.; VON SPERLING, M.. Estudo sobre a balneabilidade no rio das Velhas. Belo Horizonte: Fundação Cristiano Otoni e COPASA, 2010.

A CBPC - Companhia Brasileira de Produção Científica (CNPJ: 11.221.422/0001-03) detém os direitos materiais desta publicação. Os direitos referem-se à publicação do trabalho em qualquer parte do mundo, incluindo os direitos às renovações, expansões e disseminações da contribuição, bem como outros direitos subsidiários. Todos os trabalhos publicados eletronicamente poderão posteriormente ser publicados em coletâneas impressas sob coordenação da Sustenere Publishing, da Companhia Brasileira de Produção Científica e seus parceiros autorizados. Os (as) autores (as) preservam os direitos autorais, mas não têm permissão para a publicação da contribuição em outro meio, impresso ou digital, em português ou em tradução. 